\title{
Effectiveness of psychotherapeutic interventions targeted at adolescents with suicidal behaviors: an integrative literature review
}

Eficácia das intervençóes psicoterapêuticas dirigidas a adolescentes com comportamento suicidário: revisão integrativa da literatura

Eficacia de las intervenciones psicoterapéuticas dirigidas a adolescentes con comportamiento suicida: revisión integradora de la literatura

Rosa Maria Pereira Simóes*iD; José Carlos Pereira dos Santos**iD; Maria Júlia Costa Marques Martinho*** (iD)

\section{Abstract}

Background: The prevention of recurrent suicidal behaviors in adolescents is crucial given their size and repetitive nature, and the increased risk of death by suicide.

Objectives: To identify the current and available scientific evidence on the psychotherapeutic interventions targeted at adolescents with suicidal behaviors and to assess the effectiveness of these interventions at the level of suicidal ideation, depression, and repetition of suicidal behavior.

Methodology: Integrative literature review, through research in online bibliographic databases, with the selected search descriptors, during the publication period from January 2007 to December 2016, in English, with available references and full-text articles.

Results: Of a total of 1,847 papers found we included 10 studies on adolescents with suicidal behavior, targets of psychotherapeutic intervention, with positive results in cognitive-behavioral intervention with psychoeducation for adolescents and their families, community intervention, dialectical-behavioral therapy, and mentalization-based therapy at the level of the defined outcomes.

Conclusion: We identified psychotherapeutic interventions with effectiveness, but the heterogeneity of the studies requires thoughtful analysis and comparison of evaluated samples, methodologies, and interventions.

Keywords: primary prevention; suicide; adolescent; review

\section{Resumo}

Enquadramento: A prevenção da recorrência de comportamentos suicidários em adolescentes é fundamental dada a sua dimensão, natureza repetitiva e o risco acrescido de morte por suicídio.

Objetivos: Identificar a evidência científica atual e disponível sobre as intervençóes psicoterapêuticas dirigidas a adolescentes com comportamentos suicidários e conhecer a eficácia dessas intervençôes ao nível da ideaçáo suicida, depressão e repetiçáo do comportamento suicidário. Metodologia: Revisão integrativa da literatura, através de pesquisa em bases de dados bibliográficas online, com os descritores de pesquisa selecionados, no período de publicaçáo de janeiro de 2007 a dezembro de 2016, em inglês, com referências disponíveis e artigos em texto integral.

Resultados: Dos 1.847 artigos encontrados, foram incluídos 10 estudos com adolescentes com comportamento suicidário, alvo de intervenção psicoterapêutica, com resultados positivos com a intervenção cognitivo comportamental com psicoeducação para adolescentes e familiares, intervenção comunitária, terapia dialético comportamental e terapia da mentalização ao nível dos outcomes definidos.

Conclusão: Identificaram-se intervençốes psicoterapêuticas com eficácia, mas a heterogeneidade dos estudos exige uma análise e comparação cuidadas das amostras, metodologias e intervençóes avaliadas.

Palavras-chave: prevenção primária; suicídio; adolescente; revisão

*MSc., RN, Hospital and University Center of Coimbra, 3000-075, Coimbra, Portugal [rosasimoes18@gmail.com].(D https://orcid.org/0000-0002-6861-4928. Contribution to the article: bibliographical research, selection of articles for integrative review, and writing of the article. Address for correspondence: Estrada Espírito Santo das Touregas, $\mathrm{n}^{\circ} 98,3045-059$ Coimbra, Portugal.

**Ph.D., Coordinating Professor, Nursing School of Coimbra, 3046-851 Coimbra, Portugal [jcsantos@esenfc.pt]. (1) https://orcid.org/0000-0003-1574-972X. Contribution to the article: review of selected articles, elaboration of the table of articles, and final revision. ***Ph.D., Adjunct Professor, Nursing School of Porto, 4200-072, Porto, Portugal [julia@esenf.pt]. (1) http://orcid.org/0000-0002-5233-8324. Contribution to the article: final revision.

\section{Resumen}

Marco contextual: La prevención de la recurrencia de comportamientos suicidas en adolescentes es fundamental dada su dimensión, naturaleza repetitiva y riesgo adicional de muerte por suicidio.

Objetivos: Identificar la evidencia científica actual y disponible sobre las intervenciones psicoterapéuticas dirigidas a adolescentes con comportamientos suicidas y conocer la eficacia de dichas intervenciones al nivel de la ideación suicida, la depresión y la repetición del comportamiento suicida.

Metodología: Revisión integradora de la literatura, a través de una búsqueda en bases de datos bibliográficas en línea, con los descriptores de búsqueda seleccionados, en el período de publicación de enero de 2007 a diciembre de 2016, en inglés, con las referencias disponibles y los artículos en el texto integral.

Resultados: De los 1.847 artículos encontrados, se incluyeron 10 estudios con adolescentes con comportamiento suicida, objeto de intervención psicoterapéutica, con resultados positivos con la intervención cognitivo-comportamental con psicoeducación para adolescentes y familiares, la intervención comunitaria, la terapia dialéctico comportamental y la terapia de mentalización al nivel de los resultados definidos.

Conclusión: Se identificaron psicoterapias con eficacia, pero la heterogeneidad de los estudios exige un análisis y una comparación cuidadas de las muestras, las metodologías y las intervenciones evaluadas.

Palabras clave: prevención primaria; suicidio; adolescente; revisión

Received for publication: 07.05 .18

Accepted for publication: 21.01.19 


\section{Introduction}

Suicidal behaviors in adolescents are a public health problem and cover all and any act by which a person causes an injury to him/herself, regardless of the degree of lethal intent and knowledge of the exact reason of such act. Suicidal ideation encompasses the thoughts and cognitions about ending a person's own life, suicidal acts correspond to suicide attempts and consummated suicide, and self-harming behaviors are behaviors without suicidal intention but involve intentional self-harming acts (Direção-Geral da Saúde, 2013). Suicide is the second leading cause of death in adolescents from 15 to 19 years old and the repetitive nature of suicidal behaviors mean they are the most significant predictors of future suicidal behaviors and eventual death by suicide with an increased risk of repetition in 3 to 6 months following the behavior (Ougrin, Tranah, Stahl, Moran, \& Asarnow, 2015). The estimates of the risk of repetition in the first year after suicidal behavior vary between 5 and $15 \%$ a year, and 9 years after a suicide attempt approximately 3 to $12 \%$ of individuals have died by suicide (Wright-Hughes et al., 2015).

The period after the suicidal behavior is crucial for the implementation of strategies of prevention of future behavior since it is a period in which the individual presents a high risk of death by suicide and the absence of supervision is associated with an increased risk of retry and death by suicide (Center of Research Excellence in Suicide Prevention [CRESP], 2015). Nevertheless, Mehlum et al. (2014) found that only $10 \%$ to $20 \%$ of adolescents with self-harming behavior received some subsequent treatment and even less reported having received treatment in specialized psychiatric services for children and adolescents.

The available international scientific evidence allows us to confirm the existence of a wide range of studies that aim to reduce suicidal behavior in adolescents, whose analysis verified the existence of a wide disparity of results. These results justify this integrative review because our purpose is to compile the knowledge about the psychotherapeutic interventions targeted at adolescents with suicidal behavior. Thus, we aim to increase the body of existing knowledge and generate evidence for the implementation of these interventions in clinical practice, since there is in Portugal no known studies that implement and evaluate structured programs in suicide prevention in adolescents, nor there is evidence from studies of effectiveness.

For some authors, the most promising interventions are the cognitive-behavioral therapy, dialectical-behavioral therapy, and mentalization-based therapy (Hawton et al., 2015; Hvid et al., 2011; Ougrin et al., 2015). Green et al. (2011) consider that the best results occurred through the therapy of problem resolution and emergency contact card. In contrast, for Gonzales and Bergstrom (2013), the tested psychotherapeutic interventions, some of which previously mentioned, showed comparable results to usual treatments. Thus, and aware of all the inherent complexity of the phenomenon under analysis, we seek to find consensus through an integrative literature review, with the purpose of developing a program of psychotherapeutic intervention for suicide prevention. Therefore, and according to Higgins and Green (2011), we formulated the starting question based on the PICO method. "Which psychotherapeutic interventions (I) are effective in the prevention of suicidal ideation, depression, and repetition of suicidal behaviors, $(\mathrm{O})$ in adolescents $(\mathrm{P})$ ?". We also defined the following objectives: to identify the current and available scientific evidence on the psychotherapeutic interventions targeted at adolescents with suicidal behaviors and to assess the effectiveness of psychotherapeutic interventions.

\section{Methodological procedures of integrative review}

For this integrative review we defined the following inclusion criteria: adolescents aged between 10 and 19 years with suicidal behavior (participants), psychotherapeutic interventions after suicidal behavior (type of interventions/ phenomena of interest), primary studies with quantitative designs and with described results related to the effectiveness of implementation of psychotherapeutic interventions, regarding suicidal ideation, depression, and repetition of suicidal behavior (outcomes). We employed as exclusion criteria: studies that did not concern adolescents or studies related to adolescents 
with chronic physical disease problems; studies not related to the implementation and evaluation of psychotherapeutic interventions and studies of literature review.

We performed the bibliographic research exclusively in online bibliographic databases: Embase, PsycINFO, Cochrane Central Register of Controlled Trials, MEDLINE, CINAHL Plus and, Nursing \& Allied Health Collection Comprehensive. The descriptors of the research were: self-injurious behavior, self-mutilation, self-harm, attempted suicide, suicidal ideation, adolescents, psychotherapeutic intervention, psychosocial intervention, and talking therapies. The Boolean conjugations used were "adolescent" AND "self-injurious behavior" OR "self-mutilation" OR "self-harm" OR "attempted suicide" OR "suicidal ideation" AND "psychotherapeutic intervention" OR "psychosocial intervention" OR "talking therapies".

To select the studies and identify the current scientific evidence, we considered the publication period between January 2007 and December 2016 (the last 10 years to the date of the survey, to ensure the topicality of the gathered information), in the English language, with available references, to learn how to cite the article, and full-text articles.

Two reviewers independently performed the research and identification of studies to be included in the integrative literature review during January 2017. The screening consisted of the validation of the criteria for the elaboration of the research question: participants, intervention, outcomes, and study design.

Two reviewers extracted the data independently, after creating an instrument for data extraction and a table of standardized data documentation (The Joanna Briggs Institute, 2014), which included information about: authors, year, title, place where the study was conducted, characteristics of the participants, study method, intervention description, and relevant results obtained through the implementation of the intervention and comparison of results. The synthesis of the data occurred during March and April of 2017 after the elaboration of two tables, one of which described the included studies by title, country, year, journal, and institution originating the study and the other synthesized the results found in the analyzed studies, taking into account the sample, the intervention, and the objectives, the evaluation, and the results. The summary tables were built jointly by the researchers and the synthesis with a narrative summary for quantitative data was performed independently by the two researchers.

\section{Results and interpretation}

The research strategy adopted allowed the identification of 1,847 articles, as seen in the analysis of Figure 1, of which 908 were of the Embase database, 81 of the PsycINFO database, 229 of the Cochrane Central Register of Controlled Trials database, 351 from the MEDLINE database, 174 of the CINAHL Plus database, and 104 from the Nursing and Allied Health Collection Comprehensive database. We automatically eliminated 861 because they were duplicated or not published in full text. We selected 986 articles for the title reading, and we screened 130 of these for the reading of abstracts. After this reading, we selected 47 articles for full-text reading and analysis according to the eligibility criteria. Of these 47 we excluded 37 articles because they did not meet the inclusion criteria since 15 of them included participants from other age groups, three referred to non-psychotherapeutic interventions, four did not present implementation of interventions, two did not report results, and 13 were narrative and systematic literature reviews. We included 10 studies, which manifested great heterogeneity, so no meta-analysis was carried out. 


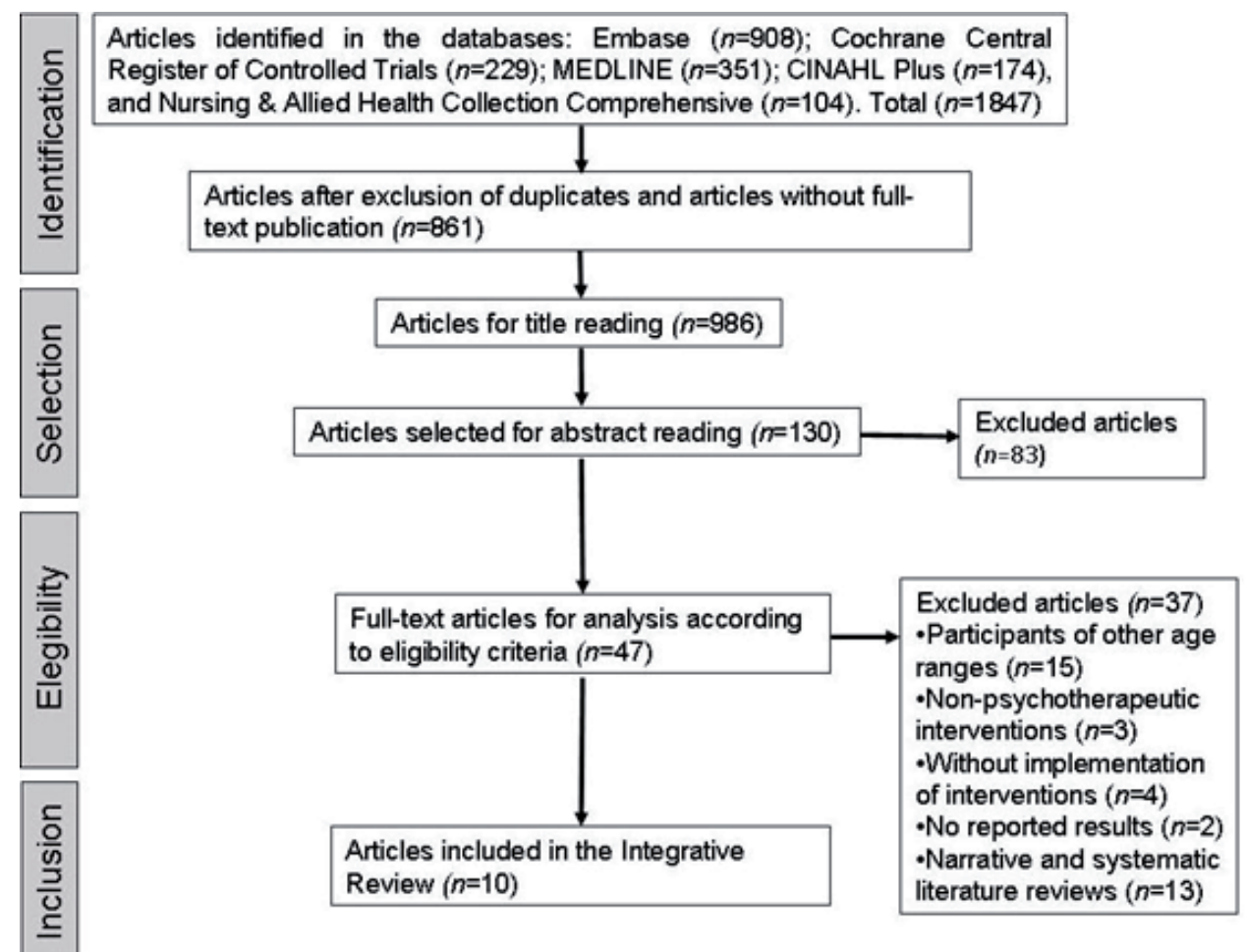

Figure1. Flowchart of the research process and selection of studies.

Table 1 presents the studies included in this review, with the name of the author, year, country, and title. They are articles published between 2009 and 2015, four of which were published in the United States of America, two in the United Kingdom, and the remain- ing in Australia, Iran, Denmark, and Norway. With the presentation of data in tables we aim to summarize and clarify the obtained results, to improve the understanding of the selected studies through the available information.

Table 1

Identification of included studies

\begin{tabular}{|c|c|c|c|c|}
\hline & Author & Year & Country & Title \\
\hline S & $\begin{array}{l}\text { Ali Alavi, Sharifi, } \\
\text { Ghanizadeh, and } \\
\text { Dehbozorgi }\end{array}$ & 2013 & Iran & $\begin{array}{l}\text { Effectiveness of cognitive-behavioral therapy in decreasing } \\
\text { suicidal ideation and hopelessness of the adolescents with } \\
\text { previous suicidal attempts }\end{array}$ \\
\hline S2 & Asarnow et al. & 2011 & USA & $\begin{array}{l}\text { An emergency department intervention for linking pediatric } \\
\text { suicidal patients to follow-up mental health treatment }\end{array}$ \\
\hline S3 & $\begin{array}{l}\text { Asarnow, Berk, } \\
\text { Hughes, and } \\
\text { Anderson }\end{array}$ & 2015 & USA & $\begin{array}{l}\text { The SAFETY Program: A Treatment-Development Trial of } \\
\text { a Cognitive-Behavioral Family Treatment for Adolescent } \\
\text { Suicide Attempters }\end{array}$ \\
\hline S4 & $\begin{array}{l}\text { Esposito-Smythers, } \\
\text { Spirito, Kahler, } \\
\text { Hunt, and Monti }\end{array}$ & 2011 & USA & $\begin{array}{l}\text { Treatment of co-occurring substance abuse and suicidality } \\
\text { among adolescents: a randomized trial }\end{array}$ \\
\hline
\end{tabular}




\begin{tabular}{|c|c|c|c|c|}
\hline S5 & Green et al. & 2011 & $\begin{array}{l}\text { United } \\
\text { Kingdom }\end{array}$ & $\begin{array}{l}\text { Group therapy for adolescents with repeated self-harm: } \\
\text { randomised controlled trial with economic evaluation }\end{array}$ \\
\hline S6 & Hazell et al. & 2009 & Australia & $\begin{array}{l}\text { Group Therapy for Repeated Deliberate Self-Harm in Ado- } \\
\text { lescents: Failure of Replication of a Randomized Trial }\end{array}$ \\
\hline S7 & Hvid et al. & 2011 & Denmark & $\begin{array}{l}\text { Preventing repetition of attempted suicide-II. The Amager } \\
\text { Project, a randomized controlled trial }\end{array}$ \\
\hline S8 & $\begin{array}{l}\text { King, Gipson, } \\
\text { Horwitz, and } \\
\text { Opperman }\end{array}$ & 2015 & USA & $\begin{array}{l}\text { Teen Options for Change: An Intervention for Young Emer- } \\
\text { gency Patients Who Screen Positive for Suicide Risk }\end{array}$ \\
\hline S9 & Mehlum et al. & 2014 & Norway & $\begin{array}{l}\text { Dialectical Behavior Therapy for Adolescents With Repeated } \\
\text { Suicidal and Self-harming Behavior: A Randomized Trial }\end{array}$ \\
\hline S10 & Rossouw and Fonagy & 2012 & $\begin{array}{l}\text { United } \\
\text { Kingdom }\end{array}$ & $\begin{array}{l}\text { Mentalization-Based Treatment for Self-Harm in Adoles- } \\
\text { cents: A Randomized Controlled Trial }\end{array}$ \\
\hline
\end{tabular}

Table 2 identifies the participants, the intervention, and the comparison where it exists, the results and designs of studies concerning the effectiveness of psychotherapeutic interventions targeted at adolescents with suicidal behavior.

Table 2

Summary of the data extracted after critical evaluation of studies

\begin{tabular}{|c|c|c|c|c|c|}
\hline & Participants & Intervention & Comparison & Results & Design \\
\hline S1 & $\begin{array}{l}30 \text { adolescents (12-18 } \\
\text { years), depressed with } \\
\text { suicide attempts in } \\
\text { the last } 3 \text { months }\end{array}$ & $\begin{array}{l}\text { Program of cog- } \\
\text { nitive-behavioral } \\
\text { therapy, with } \\
\text { psychoeducation }\end{array}$ & $\begin{array}{l}\text { Significant dif- } \\
\text { ferences in the } \\
\text { pre and post-in- } \\
\text { tervention scores } \\
\text { (for suicidal } \\
\text { ideation and } \\
\text { hopelessness) in } \\
\text { the intervention } \\
\text { group compared } \\
\text { with the control } \\
\text { group }\end{array}$ & $\begin{array}{l}\text { Suicidal ideation } \\
\text { and hopelessness } \\
\text { decreased in the } \\
\text { intervention } \\
\text { group, with signifi- } \\
\text { cant differences }\end{array}$ & $\begin{array}{l}\text { Randomized } \\
\text { controlled clinical } \\
\text { study }\end{array}$ \\
\hline S2 & $\begin{array}{l}181 \text { suicidal adoles- } \\
\text { cents } \\
(10-18 \text { years old })\end{array}$ & $\begin{array}{l}\text { Family interven- } \\
\text { tion for suicide } \\
\text { prevention }\end{array}$ & $\begin{array}{l}\text { Intervention } \\
\text { group without } \\
\text { significant } \\
\text { reductions in } \\
\text { relation to the } \\
\text { control group }\end{array}$ & $\begin{array}{l}\text { Without signifi- } \\
\text { cant reductions in } \\
\text { suicide attempts, } \\
\text { suicidal ideation, } \\
\text { depression, or de- } \\
\text { pression of parents }\end{array}$ & $\begin{array}{l}\text { Randomized } \\
\text { controlled clinical } \\
\text { study }\end{array}$ \\
\hline S3 & $\begin{array}{l}35 \text { adolescents } \\
\text { (11-18 years old) } \\
\text { with self-harm with } \\
\text { suicidal intent }\end{array}$ & $\begin{array}{l}\text { Cognitive-behav- } \\
\text { ioral intervention } \\
\text { in the adolescent } \\
\text { and the family }\end{array}$ & & $\begin{array}{l}\text { Improvements in } \\
\text { hopelessness, social } \\
\text { support, suicidal } \\
\text { ideation, depres- } \\
\text { sion in adolescents } \\
\text { and parents }\end{array}$ & $\begin{array}{l}\text { Not controlled, } \\
\text { non-randomized, } \\
\text { double-blind, } \\
\text { clinical study }\end{array}$ \\
\hline
\end{tabular}




\begin{tabular}{|c|c|c|c|c|c|}
\hline S4 & $\begin{array}{l}40 \text { adolescents (mean } \\
\text { age of } 15 \text { years) with } \\
\text { suicide attempt in the } \\
\text { last } 3 \text { months }\end{array}$ & $\begin{array}{l}\text { Cognitive-behav- } \\
\text { ioral treatment, } \\
\text { with motivational } \\
\text { interview }\end{array}$ & $\begin{array}{l}\text { More suicide } \\
\text { attempts in the } \\
\text { control group } \\
\text { than in the in- } \\
\text { tervention group }\end{array}$ & $\begin{array}{l}\text { Less suicide at- } \\
\text { tempts, psychiatric } \\
\text { hospitalization, } \\
\text { visits to emergen- } \\
\text { cy services and } \\
\text { prisons }\end{array}$ & $\begin{array}{l}\text { Randomized } \\
\text { controlled clinical } \\
\text { study }\end{array}$ \\
\hline S5 & $\begin{array}{l}366 \text { adolescents (12- } \\
17 \text { years old) with } \\
\text { a minimum of two } \\
\text { self-harmings a year }\end{array}$ & $\begin{array}{l}\text { Program of group } \\
\text { psychotherapy } \\
\text { for self-harming } \\
\text { adolescents }\end{array}$ & & $\begin{array}{l}\text { The group ther- } \\
\text { apy did not im- } \\
\text { prove the results } \\
\text { concerning the } \\
\text { self-harming }\end{array}$ & $\begin{array}{l}\text { Randomized and } \\
\text { blind study of } \\
\text { parallel groups }\end{array}$ \\
\hline S6 & $\begin{array}{l}72 \text { adolescents (12-16 } \\
\text { years old) }\end{array}$ & $\begin{array}{l}\text { Group interven- } \\
\text { tion with cogni- } \\
\text { tive-behavioral } \\
\text { therapy and social } \\
\text { skills training }\end{array}$ & $\begin{array}{l}\text { Improvement } \\
\text { of overall symp- } \\
\text { toms in the } \\
\text { experimental } \\
\text { group compared } \\
\text { to the control } \\
\text { group }\end{array}$ & $\begin{array}{l}\text { No improvement } \\
\text { of variables: repet- } \\
\text { itive self-harming, } \\
\text { use of overdosage, } \\
\text { and time for } \\
\text { the repetition of } \\
\text { self-harming }\end{array}$ & $\begin{array}{l}\text { Randomized and } \\
\text { blind study of } \\
\text { parallel groups }\end{array}$ \\
\hline S7 & $\begin{array}{l}133 \text { adolescents } \\
\text { (12-18 years old) }\end{array}$ & $\begin{array}{l}\text { Baerum model } \\
\text { of Norway: fast } \\
\text { action of active } \\
\text { awareness and } \\
\text { continuity of } \\
\text { contact }\end{array}$ & $\begin{array}{l}\text { Less self-harm- } \\
\text { ing in the inter- } \\
\text { vention group }\end{array}$ & $\begin{array}{l}\text { Less repetition of } \\
\text { attempted suicide } \\
\text { and repetitive acts } \\
\text { in the intervention } \\
\text { group }\end{array}$ & $\begin{array}{l}\text { Randomized } \\
\text { and prospective } \\
\text { controlled clinical } \\
\text { study }\end{array}$ \\
\hline S8 & $\begin{array}{l}49 \text { adolescents (14-19 } \\
\text { years old) with risk of } \\
\text { suicide, in the emer- } \\
\text { gency service }\end{array}$ & $\begin{array}{l}\text { Brief intervention } \\
\text { with motivational } \\
\text { interview, crisis } \\
\text { card, psychoed- } \\
\text { ucation and in- } \\
\text { formation about } \\
\text { services }\end{array}$ & $\begin{array}{l}\text { Significant } \\
\text { reduction } \\
\text { in suicidal } \\
\text { ideation and } \\
\text { hopelessness in } \\
\text { adolescents in } \\
\text { the intervention } \\
\text { group }\end{array}$ & $\begin{array}{l}\text { Positive effects } \\
\text { for depression } \\
\text { and hopelessness; } \\
\text { Non-significant } \\
\text { impact in suicidal } \\
\text { ideation }\end{array}$ & $\begin{array}{l}\text { Randomized } \\
\text { controlled clinical } \\
\text { study }\end{array}$ \\
\hline S9 & $\begin{array}{l}77 \text { adolescents (12- } \\
18 \text { years old) with } \\
\text { recent and repetitive } \\
\text { self-harming }\end{array}$ & $\begin{array}{l}\text { Dialectical-be- } \\
\text { havioral therapy } \\
\text { for adolescents } \\
\text { (DBT) }\end{array}$ & $\begin{array}{l}\text { Therapy group } \\
\text { with less self-in- } \\
\text { jury, suicidal } \\
\text { ideation, and } \\
\text { depression in } \\
\text { comparison to } \\
\text { the usual treat- } \\
\text { ment }\end{array}$ & $\begin{array}{l}\text { Reduction of } \\
\text { depression and } \\
\text { self-harming; Re- } \\
\text { duction of suicidal } \\
\text { ideation with a } \\
\text { difference between } \\
\text { groups }\end{array}$ & $\begin{array}{l}\text { Randomized } \\
\text { controlled clinical } \\
\text { study }\end{array}$ \\
\hline S10 & $\begin{array}{l}80 \text { adolescents (12-17 } \\
\text { years old) }\end{array}$ & $\begin{array}{l}\text { Program of } \\
\text { psychotherapy } \\
\text { with individual } \\
\text { sessions and men- } \\
\text { talization-based } \\
\text { family therapy }\end{array}$ & $\begin{array}{l}\text { The therapy } \\
\text { group had a } \\
\text { significant } \\
\text { reduction in } \\
\text { self-aggression } \\
\text { and depression } \\
\text { concerning the } \\
\text { usual treatment }\end{array}$ & $\begin{array}{l}\text { Self-harming and } \\
\text { depression de- } \\
\text { creased, with sta- } \\
\text { tistically significant } \\
\text { differences in the } \\
\text { therapy group }\end{array}$ & $\begin{array}{l}\text { Randomized } \\
\text { controlled clinical } \\
\text { study }\end{array}$ \\
\hline
\end{tabular}


As they are experimental and mostly randomized clinical studies, controlled with multiple evaluations, it was possible to evaluate the effectiveness of various psychotherapeutic interventions targeted at adolescents with suicidal behavior. The particular analysis of selected studies found some homogeneity in the study design, but a considerable heterogeneity concerning the formulated objectives, the studied variables, the type of psychotherapeutic intervention, and the type of sample.

The sample of included studies includes adolescents with 10 to 19 years of age, and we verified a tendency for the study of adolescents with 12 to 18 years of age. In general, the studies evaluated the effectiveness of psychotherapeutic interventions targeted at adolescents with suicidal behavior, before and after the intervention, and in some studies, 3, 6, or 12 months after the intervention. Mostly, the psychotherapeutic interventions were evaluated in comparison with the usual treatment and used as an assessment method the questionnaires applied in different moments.

As regards the type of implemented psychotherapeutic interventions, they were mostly of cognitive-behavioral therapy with psychoeducation (differing among themselves in type and methodology of the sessions, topics, and persons involved) and also family therapy, group therapy, brief interventions, interventions of care continuity, dialectical-behavioral therapy, and mentalization-based psychotherapy.

As regards the results obtained by the implementation of psychotherapeutic interventions, we found that in six analyzed studies the results were positive, in three they were null, and in two they were mixed. In the studies that showed positive results, there was an improvement in the specific variables of suicidal behavior. Study 1 (S1), conducted by Ali Alavi, Sharif, Ghanizadeh, and Dehbozorgi (2013), they concluded that the program of cognitive-behavioral therapy for suicide prevention, including psycho-educative interventions and modules of individual and family skills training, was effective in decreasing suicidal ideation and hopelessness in depressed adolescents with previous attempts of suicide. Also, Asarnow, Berk, Hughes, and Anderson (2015), when implementing the Safety program (S3), concluded the effectiveness of the program, noting statistically significant improvements in the measures of suicidal behavior, hopelessness, suicidal ideation, depression in adolescents and parents, and social support of adolescents. The research developed by Esposito-Smythers, Spirito, Kahler, Hunt, and Monti (2011) concluded that the program's target-adolescents showed less overall endangerment, fewer suicide attempts, fewer episodes of psychiatric hospital care, fewer trips to emergency services and prisons, with statistically significant differences (S4). Positive results also occurred in the community intervention program developed and implemented by Hvid et al. (2011) that allowed concluding that there were fewer suicidal behaviors in the intervention group compared with the control group. These differences were statistically significant, and this program was implemented by a team composed of a psychiatrist and two nurse specialists in mental health nursing and psychiatry (S7). Also, Mehlum et al. (2014) concluded that the dialectical-behavioral therapy was more effective compared with the usual care, as it reinforces the reduction of injury, suicidal ideation, and depressive symptoms (S9). The last study that showed positive results was Study 10 (S10), developed by Rossouw and Fonagy (2012), which concluded that mentalization-based therapy was more effective than the usual treatment in reducing self-aggression and depression.

Studies with mixed results found no significant differences in the variables related to suicidal behavior but found significant differences in favor of the intervention group in other psychological dimensions. One of these studies, developed by Hazell et al. (2009), showed that the group therapy presents better results than the usual care in preventing the recurrence of self-harming behavior in adolescents with at least two previous self-harming episodes (S6). The researchers noted that, despite a tendency towards improvement over time in the rates of overall symptoms in the experimental group compared with the control group, there is no statistically significant difference in the proportion of repetition of self-harming behavior after 6 months and in the interval of 6 to 12 months. Concerning the proportion of adolescents who used the overdosage at least once or more than once, there were no differences between the treatment group and the control 
group concerning the time for the first repetition of suicidal behavior. Also King, Gipson, Horwitz, and Opperman (2015), when analyzing the feasibility and the short-term efficiency of change options for adolescents, through a brief intervention in the emergency service, concluded that, although the intervention's target-adolescents manifested statistically significant reductions in depressive symptoms in comparison to the adolescents of the usual treatment group, the brief intervention had no significant impact on suicidal ideation and the use of mental health services after the episode in the emergency service (S8).

The studies that were deemed null showed results that did not improve specific variables of suicidal behavior, nor others analyzed, and we included two studies in this group. The study conducted by Asarnow et al. (2011) concluded that family intervention has not led to significant reductions in attempts of suicide, suicidal ideation, depression, and other mental health/ functioning problems, depression of parents, and family functioning (S2). Besides, Green et al. (2011) concluded that, despite overall improvements, they did not observe additional advantages of the group therapy program on the usual routine care (S5).

The obtained results contradict the results of a systematic literature review published by Gonzales and Bergstrom (2013) since all studied psychotherapeutic interventions presented results comparable to those obtained with the usual treatments. The common interventions, including relaxation techniques, have minimal evidence, suggesting that patients may perceive them as harmful. In a systematic literature review that analyzed 19 randomized clinical trials, including psychological and social interventions and not pharmacological interventions, Ougrin et al. (2015) concluded that the proportion of self-harmed adolescents during the follow-up period was lower in intervention groups (28\%) than in control groups (33\%). The psychotherapeutic interventions with the more significant effect volumes were dialectical-behavioral therapy, cognitive-behavioral therapy, and mentalization-based therapy. To Hawton et al. (2015) there is little support for group psychotherapy's effectiveness in adolescents with multiple episodes of suicidal behavior. Moreover, similarly to the author above, the results for the mentalization-based therapy and dialectical-behavioral therapy mean that these approaches warrant a more in-depth evaluation.

We found that there are methodological limitations that hinder the consensus regarding the effectiveness of psychotherapeutic interventions in suicide prevention in adolescents, which affects the efforts for the implementation of best clinical practices. It is fundamental to conduct controlled clinical trials on the effects of this type of interventions and to develop new psychotherapeutic interventions in collaboration with adolescents and their families, given their social representations of the phenomenon, to ensure that the implemented intervention model can satisfy their needs and expectations (CRESP, 2015).

\section{Conclusion}

The existing epidemiological data prove the high prevalence of recurrent suicidal behaviors among adolescents, as no consensual scientific evidence corroborates the effectiveness of psychotherapeutic interventions. Thus, the objectives of this review were to identify the current and available scientific evidence on psychotherapeutic interventions targeted at adolescents with suicidal behavior and to assess their effectiveness.

We identified 1,847 articles and included 10 of them in this integrative literature review. In general, the studies evaluated suicidal ideation, repetition, and risk of suicidal behavior, but also hopelessness, depressive symptoms, social support, and self-esteem, at various times depending on the study's design. We were able to verify that these studies show considerable heterogeneity in their objectives, methodology, type of psychotherapeutic intervention, and type of sample.

The majority of studies with positive results addressed single-family, cognitive-behavioral intervention, with psychoeducation and training of individual and family skills, community intervention, dialectical-behavioral therapy, and mentalization-based therapy at the level of suicidal ideation, depression, and repetition of suicidal behavior. We considered as limitations of this study the existence of studies with significant methodological differences that hindered the comparability and generalization of results, the inclusion criterion of written language (En- 
glish only), and the use of a few terms related with the participants (only adolescent), which may have contributed to the loss of potential studies. The selected period, the full-text filter, the non-clarification of the adjustments made to the different consulted databases, and not updating the research to the current date are also limitations to this study.

The found results allow answering the research question and understanding that there are psychotherapeutic interventions with effectiveness in preventing the repetition of suicidal behaviors and show promising results in the decrease of suicidal ideation, depression, and repetition of the behavior. However, it is not possible to compare the included studies, since they are not homogeneous regarding the sample, the measures of suicidal behavior, or the implemented interventions.

As regards the implications for research, we reinforce the need to promote further research on the topic under analysis with validation and assessment of psychotherapeutic interventions that are effective in preventing the repetition of suicidal behavior in adolescents, with similar methodologies, to increase the capacity of comparison and possibility of creating clinical evidence recommendations. As regards the implications for practice, we can state that in this age range it is seemingly clear that a structured and systemic intervention shows more effective results and, therefore, a practice to follow.

\section{References}

Ali Alavi, M. D., Sharifi, B., Ghanizadeh, A., \& Dehbozorgi, G. (2013). Effectiveness of cognitive-behavioral therapy in decreasing suicidal ideation and hopelessness of the adolescents with previous suicidal attempts. Iranian Journal of Pediatrics, 23(4), 467-72. Retrieved from https://www.ncbi.nlm.nih.gov/pmc/ articles/PMC3883378/

Asarnow, J. R., Baraff, L. J., Berk, M., Grob, C. S., Devich-Navarro, M., Suddath, R., ... Tang, L. (2011). An emergency department intervention for linking pediatric suicidal patients to follow-up mental health treatment. Psychiatric Services: A Journal of the American Psychiatric Association, 62(11), 1303-1309. Retrieved from https://www.ncbi.nlm.nih.gov/pmc/ articles/PMC3251923/.

Asarnow, J. R., Berk, M., Hughes, J. H., \& Anderson, N.
L. (2015). The SAFETY Program: A treatment-development trial of a cognitive-behavioral family treatment for adolescent suicide attempters. Journal of Clinical Child \& Adolescent Psychology, 44(1), 194-203. Retrieved from https://www.ncbi.nlm.nih. gov/pmc/articles/PMC4289426/

Centre of Research Excellence in Suicide Prevention. (2015). Care after a suicide attempt. Retrieved from http://www.coordinare.org.au/news/mental-healthreport-released-care-after-a-suicide-attempt/

Direção-Geral da Saúde. (2013). Plano Nacional de Prevenção do Suicídio 2013/2017. Retrieved from https:// www.dgs.pt/documentos-e-publicacoes/plano-nacional-de-prevencao-do-suicido-20132017.aspx

Esposito-Smythers, C., Spirito, A., Kahler, C. W., Hunt, J., \& Monti, P. (2011). Treatment of co-occurring substance abuse and suicidality among adolescents: A randomized trial. Journal of Consulting and Clinical Psychology, 79(6), 728-739. doi:10.1037/a0026074

Gonzales, A. H., \& Bergstrom, L. (2013). Adolescent non-suicidal self-injury (NSSI) interventions. Journal of Child and Adolescent Psychiatric Nursing, 26, 124-30. Retrieved from https://www.ncbi.nlm.nih. gov/pubmed/23607824

Green, J. M., Wood, A. J., Kerfoot, M. J., Trainor, G., Roberts, C., Rothwell, J., ... Harrington, R. (2011). Group therapy for adolescents with repeated selfharm: Randomised controlled trial with economic evaluation. BMJ, 342(682). doi: 10.1136/bmj.d682

Hawton, K., Witt, K. G., Taylor-Salisbury, T. L., Arensman, E., Gunnell, D., Hazell, P., ... van Heeringen, K. (2015). Pharmacological interventions for self-harm in adults. Cochrane Database of Systematic Reviews 6(7). Retrieved from https://www.ncbi.nlm.nih.gov/ pubmed/26147958

Hazell, P. L., Martin, G., McGill, K., Kay, T., Wood, A., Trainor, G., \& Harrington, R. (2009). Group therapy for repeated deliberate self-harm in adolescents: Failure of replication of a randomized trial. Journal of the American Academy of Child \& Adolescent Psychiatry, 48(6), 662-70. Retrieved from http://www.sciencedirect.com/science/article/pii/S0890856709600952

Higgins, J., \& Green, S. (2011). Cochrane handbook for systematic reviews of interventions: Version 5.1.0. The Cochrane Collaboration. Retrieved from http:// handbook.cochrane.org/

Hvid, M., Vangborg, K., Sorensen, H. J., Nielsen, I. K., Stenborg, J. M., \& Wang, A. G. (2011). Preventing repetition of attempted suicide-II. The Amager Project, a randomized controlled trial. Nordic journal of psychiatry, 10. Retrieved from https://www.ncbi. nlm.nih.gov/pubmed/21171837. 
King, C. A., Gipson, P. Y., Horwitz, A. G., \& Opperman, K. J. (2015). Teen options for change: An intervention for young emergency patients who screen positive for suicide risk. Psychiatric Services, 66(1). doi:10.1176/appi.ps.201300347

Mehlum, L., Tormoen, A. J., Ramberg, M., Haga, E., Diep, L. M., Laberg, S., ... Groholt, B. (2014). Dialectical behavior therapy for adolescents with repeated suicidal and self-harming behavior: A randomized trial. Journal of the American Academy of Child \& Adolescent Psychiatry, 53(10), 1082-1091. Retrieved from http://www.sciencedirect.com/science/article/pii/S0890856714004997

Ougrin, D., Tranah, T., Stahl, D., Moran, P., \& Asarnow, J. R. (2015). Therapeutic interventions for suicide attempts and self-harm in adolescents: Systematic review and meta-analysis. Journal of the American Academy of Child and Adolescent Psychiatry, 54, 97107. Retrieved from http://www.sciencedirect.com/
science/article/pii/S089085671400731X

Rossouw, T. I., \& Fonagy, P. (2012). Mentalization-based treatment for self-harm in adolescents: A randomized controlled trial. Journal of the American Academy of Child \& Adolescent Psychiatry, 51(12), 1304-1313. e3. Retrieved from http://www.sciencedirect.com/ science/article/pii/S0890856712007368

The Joanna Briggs Institute. (2014). Joanna Briggs Institute reviewers' manual: 2014 edition. Adelaide, Australia: Author. Retrieved from http://joannabriggs. org/assets/docs/sumari/ reviewersmanual-2014.pdf

Wright-Hughes, A., Graham, E., Farrin, A., Collinson, M., Boston, P., Eisler, I., ... Cottrell, D. (2015). Self-harm intervention: Family therapy (SHIFT), a study protocol for a randomised controlled trial of family therapy versus treatment as usual for young people seen after a second or subsequent episode of self-harm. Trials, 16, 501. Retrieved from https:// www.ncbi.nlm.nih.gov/pubmed/26537599 